\title{
The Modifying Factor of Lead Exposure Time with Blood Lead Levels on Adulterated Paint Worker
}

\author{
Diah Lestari ${ }^{1, *}$, and Angki Purwanti ${ }^{2}$ \\ ${ }^{1}$ Health Polytechnic of Jakarta III \\ Jakarta, Indonesia \\ Email: diahtari1411 [AT] gmail.com \\ ${ }^{2}$ Health Polytechnic of Jakarta III \\ Jakarta, Indonesia \\ Email: angki_purwanti [AT] yahoo.com \\ ${ }^{*}$ Corresponding author: Diah Lestari
}

\begin{abstract}
The modifying factor for exposure time for paint workers who work more than 8 hours / day have abnormal blood lead levels $>10 \mu \mathrm{g} / \mathrm{dl}$. Lead exposure to paint workers occurs when mixing paints, mostly through air, skin, through food and drinks. The longer the work, the more the amount of lead exposure received, although the amount of lead absorbed by the body is only small, this metal turns out to be very dangerous and can cause health problems due to the buildup of lead in the body. The presence of lead $(P b)$ in the blood can cause severe and dangerous effects including interfering with the hematopoietic system, a long exposure can disrupt the gastrointestinal system, central nervous system, immune system, kidneys. The purpose of this research was to determine the relationship and closeness of the relationship between the modification factors of exposure time with blood lead levels of adulterated paint workers in the area of East Jakarta. The research method uses primary data through an analytic observational cross-sectional design approach. Sampling is done by non-probability sampling with consecutive sampling techniques. The correlation test used was the Spearman test with a confidence level of 95\%. The results of the research found that the average exposure time of adulterated paint workers was 48.9 hours/week exceeding the permissible work time, and the exposure time $>40$ hours/week was $77.5 \%$ of the number of respondents. The average blood lead level was 0.15 $\mathrm{mg} / \mathrm{L}$, with the highest blood lead level $0.45 \mathrm{mg} / \mathrm{L}$ and workers with exposure times $>40$ hours/week obtained blood lead levels exceeding the safe reference limit $(40 \mathrm{mg} / \mathrm{L})$ of $19.4 \%$. The conclusion is that there is a significant relationship between duration of exposure and lead level of adulterated paint workers $(p-v a l u e=0.029)$ and shows the moderate closeness of the relationship with the direction of a positive relationship. The value of $r=0.346$, means that the longer the person is exposed to lead, the higher the level of lead in the blood of adulterated paint workers. The discussion of modification factors of exposure time in adulterated paint workers can influence lead exposure continuously, in the long term, absorption of lead in the body $99 \%$ which is bound to erythrocytes will accumulate in the blood, then it is distributed into the blood which is $90 \%$ binding to cells red blood cells (erythrocytes), and the rest are bound to blood plasma. Once absorbed, the lead will be stored in the blood for 35 days. For 8 hours, a worker can absorb up to $400 \mu g$ and add $20-30 \mu \mathrm{g} /$ day from food, drinks, and air. The presence of lead in blood represents a reflection of the dynamic continuity between exposure, absorption, distribution, and excretion, so that it is one indicator to know and follow ongoing exposure.
\end{abstract}

Keywords--- Modifying Effect, Exposure Time, Relationship Strength, Blood Lead Levels

\section{INTRODUCTION}

Lead levels in the environment continue to increase along with human activities in the industrialization process (Pahlawan, S., Keman, 2014). Lead is widely used by humans in industrial activities. One of them is used as a coloring agent. The paint contains lead when paint manufacturers deliberately add one or more lead compounds to the paint, during the manufacturing process (Ismawati et al., 2015). Based on research conducted by the International Organization Promoting Safe Chemical Policies and Practices that Protect Human Health and the Environment, states that about $77 \%$ of paint samples sold in Indonesia after being tested contain lead with an average level of 17,300 ppm or nearly 200 times more than the recommended level of $90 \mathrm{ppm}$ (Muliyadi, 2015).

Paint is one source of lead exposure that uses lead metal as a pigment material (Mulfiyanti, 2017). Aside from being a pigment material, lead can also be used as a dryer and anti-corrosion or inhibit rusting. Over time, the growth of the Indonesian paint market is among the fastest in the world, among others by 10\% from 2011 to 2012 after an increase of 
8\% per year between 2006 and 2011. The potential for improvement in the coming years is still high, given the large population and high economic growth rates (Ismawati et al, 2013). One type of paint shop that is commonly found in Indonesia is adulterated paint shops. Based on preliminary surveys conducted by researchers, the large number of adulterated paint shops is proportional to a large number of requests from the public. This is because adulterated paint can be used for various objects, such as wood, vehicles, walls, etc., and we can order colors according to the desired taste because of the large selection of paint colors, making it more efficient and efficient because one type of paint color can be used as a color variation through the mixing process. Besides, the mixing process can use the rest of the paint that has not been used to produce new colors.

Research conducted by Ismawati (2015) by buying 121 paint samples from various shops and outlets around Denpasar, Bogor, Depok, Tangerang, and Jakarta. From the sample studied, it was found that $83 \%$ of the paint contained lead above $90 \mathrm{ppm}$, the maximum number of lead content allowed in many industrialized countries. The high rate of lead content in paint allows people who work in the painting field to be exposed to lead, so it is very possible to find lead levels in the blood.

Lead levels in the blood can be influenced by several internal modifiers (non-modifiable) and external (modifiable) workers which include workers age, sex, dose of exposure, consumption patterns, nutritional status, length of exposure, length of service, use of personal protective equipment ( PPE), smoking habits, availability of sanitation facilities, as well as hygiene and sanitation behavior of workers (Humairo and Keman, 2017). Based on research conducted by Pusparini et al, in 2016 of 32 respondents painting workers, as many as $94.4 \%$ of workers who have the habit of smoking have abnormal blood lead levels. Based on the use of PPE as many as $88.5 \%$ of workers who use PPE do not meet the requirements of having blood lead levels exceeding the threshold. Based on the exposure time as much as $90.3 \%$ of workers who work more than 8 hours have abnormal blood lead levels (> $10 \mu \mathrm{g} / \mathrm{dL})$.

The results of preliminary observations conducted by researchers on adulterated paint workers in the Jakarta area, on average, adulterated paint workers mix dyes conventionally and don't use personal protective equipment (PPE) such as masks and gloves when mixing colors because they are uncomfortable and can hamper performance, which can cause workers to easily be exposed to lead contained in paint through inhalation and skin. Workers who don't use masks can inhale the lead contained in the paint used so that lead can be absorbed by the body through breathing (Sari, Setiani, and Joko, 2016). Another thing that can lead to the entry of lead into the body is that when workers do the process of mixing the colors don't wear gloves so susceptible to exposure through the skin and ingestion if the hands still contain paint when eating with bare hands ( $N$, Rizkiani, 2004). In a study conducted by Kasanah in 2016 on body painting workers in Semarang as much as $85.3 \%$ showed the results of blood lead levels above the maximum limit that is above $10 \mu \mathrm{g} / \mathrm{dl}$. Lead exposure in the painting process mostly occurs through the air, and can also be through the skin although it's very small (Rizkiani, 2004).

In 2017 Lutfi, Yustina, and Ahmad conducted a study of 12 respondents of car painting workers, respondents who had 12-30 months of work had average lead levels of $22.93 \mu \mathrm{g} / \mathrm{dL}$, then workers who had longer hours of work were $>60$ months had a higher lead level which was $32.67 \mu \mathrm{g} / \mathrm{dL}$. Based on the habit of using PPE from 12 respondents only 2 people who use PPE in the form of masks so that lead levels in the body are still within normal limits, and 10 respondents do not use PPE it is seen that $70 \%$ of respondents have high lead levels and $30 \%$ have normal lead levels.

Lead exposure to humans can cause various negative effects on health, including on the hematological system. This is consistent with research conducted by Sari and Lubis in 2014, that exposure to lead and iron deficiency anemia often occur simultaneously and indicate severe anemia. On exposure to lead with low levels that last continuously for a long time will cause health effects including anemia (Mawardi and Setiani, 2013). Disorders of haemapoitic activity, nervous system, urinary system, gastrointestinal system, cardiovascular system, reproductive system, endocrine system, and disrupting the musculoskeletal system such as bones and teeth (Moelyaningrum, 2016). 99\% of the lead absorbed by the body is bound to erythrocytes, and $1 \%$ is spread freely into the soft tissues and bones so that blood lead levels represent lead levels in the body (Lubis et al, 2013). Also, modifying factors that cause blood lead levels to reflect the reflection of dynamic continuity between exposure, absorption, distribution, and excretion to be one indicator to know and follow ongoing exposure (Ardillah, 2016).

Modifying factors that make the absorption of lead increase in blood levels, resulting in a decrease in hemoglobin content, an increase in the number of reticulocytes (young erythrocytes), and an increase in the number of basophilic speckled erythrocytes. Following the results of blood tests to detect these various effects can be used as a gauge of lead exposure (Pahlawan, S., Keman, 2014). On prolonged exposure with high lead levels, the life span of erythrocytes shortens and is associated with inhibition of pyrimidine 5-nucleotidase which subsequently causes hemolytic anemia characterized by reticulocytosis (Wagiu and Wulur, 2006). 
In a study conducted by Kalahasthi and Barman in 2016, it showed that the index level of reticulocyte counts increased significantly with an increase in blood lead levels in battery factory workers. This shows that lead exposure can cause reticulocytosis by increasing the index of reticulocyte count. Hematoxics can be used to increase alertness to the effects of lead in the blood in people exposed to lead. So by knowing the modifying factors, physical properties, chemical properties, metabolism and toxic effects of lead, the diagnosis of lead poisoning in the blood can be known early and can be used to prevent lead poisoning in the community especially paint workers (Ardyanto, 2005). An even more important focus is that every job carries risks, it is feared that contaminated paint workers do not know the risks and the occurrence of lead exposure which has a serious impact on health. For this reason, this research is conducted as a first step to find out lead poisoning so that further prevention can be done.

\section{METHODS}

The study design uses quantitative research analytically observational cross-sectional methods. The population used is adulterated paint workers in paint shops located in the East Jakarta District Health Office. To obtain the minimum sample size needed in this study using the Lemeshow formula, where the total population of respondents is unknown. Nonprobability sampling or non-random sampling using a consecutive sampling technique, where respondents who meet the research criteria are included in the study until a certain time so the required number of respondents is met (Sastroasmoro and Ismael, 2010). The selected sample has inclusion and exclusion criteria, namely working as adulterated paint workers both management, storage and mix both manually (conventional) and who use automatic equipment, willing to be a respondent and willing to take blood and have worked for more than 1 year. Approval of research ethics obtained from the Health Polytechnic Commission of the Ministry of Health Jakarta III No. KEPK-PKKJ3 / 214 / IV / 2019, May 6, 2019

\section{RESULTS}

The number of samples from the paint shop at the research location in the East Jakarta District Health Office area was detected by researchers as many as 23 paint shops in 9 District Health Centers in the East Jakarta Region as 40 respondents. The technique of paint mixing is automatically as many as 4 workers and most of them do manually (conventional) as many as 36 workers.

\section{Distribution of Exposure Time on Adulterated Paint Workers}

The duration of exposure in this study refers to SNI 19-0232-2005 which contains the Time Weighted Average of the chemicals in the workplace air. Workers can be exposed to chemicals daily not more than 8 hours per day or 40 hours per week. The distribution time of exposure to paint workers can be seen in table 1 .

Tabel 1. Distribution of Exposure Time on Adulterated Paint Workers

\begin{tabular}{cccccc}
\hline $\begin{array}{c}\text { Exposure Time } \\
\text { (hours/week) }\end{array}$ & $\begin{array}{c}\text { Frequency } \\
(\mathbf{n})\end{array}$ & $\begin{array}{c}\text { Percentage } \\
(\boldsymbol{\%})\end{array}$ & Mean & $\begin{array}{c}\text { Std } \\
\text { Deviation }\end{array}$ & Min-Max \\
\hline$\leq \mathbf{4 0}$ hours & 9 & $22.5 \%$ & 48.88 & 12,67 & $30-77$ \\
\hline$>\mathbf{4 0}$ hours & 31 & $77.5 \%$ & & & \\
\hline Total & 40 & $100 \%$ & & & \\
\hline
\end{tabular}

The results in table 1 were obtained by adulterated paint workers who had exposure times $\leq 40$ hours/week, namely 30 - 36 hours/week, while workers who worked> 40 hours/week with a range of 42 - 77 hours/week.

\section{Distribution of Blood Lead Levels on Adulterated Paint Workers}

The blood lead level reference value is categorized based on the provision of the Directorate of Medical Support Services Development (BPPM) of the Director-General of Medical Services of the Ministry of Health of the Republic of Indonesia in 2008 concerning the reference value of heavy metal content in human specimens in mg/L units. Table 2 presents the results of the blood lead levels of adulterated paint workers.

Table 2. Distribution of Blood Lead Levels on Adulterated Paint Workers

\begin{tabular}{lccccc}
\hline $\begin{array}{l}\text { Blood Lead } \\
\text { Levels }\end{array}$ & $\begin{array}{c}\text { Frequency } \\
(\mathbf{n})\end{array}$ & $\begin{array}{c}\text { Percentage Mean } \\
(\boldsymbol{\%})\end{array}$ & $\begin{array}{c}\text { Std. } \\
\text { Deviation }\end{array}$ & Min-Max \\
\hline$\leq \mathbf{0 . 4 0 \mathbf { m g }} / \mathbf{L}$ & 34 & $85 \%$ & & & \\
\hline$>0.40 \mathrm{mg} / \mathrm{L}$ & 6 & $15 \%$ & 0.15 & 0,14 & $0,02-0,45$ \\
\hline Total & 40 & $100 \%$ & & & \\
\hline
\end{tabular}


From the results of an examination of blood lead levels of adulterated paint workers, it was found that who have lead levels within the reference value $\leq 0.40 \mathrm{mg} / \mathrm{L}$ with levels of $0.02-0.34 \mathrm{mg} / \mathrm{L}$ while those who have blood lead levels exceed the reference value limits with levels of $0,41-0.45 \mathrm{mg} / \mathrm{L}$.

\section{Relationship Between Exposure Time and Blood Lead Levels}

Data normality test results, for the duration of exposure with blood lead levels in table 3 are as follows:

Table 3. Data Normality Test

\begin{tabular}{lc}
\hline \multicolumn{1}{c}{ Variable } & p- value (Shapiro-wilk) \\
\hline Exposure Time & 0.032 \\
\hline Blood Lead Levels & 0.000 \\
\hline
\end{tabular}

The $\mathrm{p}$-value used in this test uses Shapiro-Wilk because the sample used is $\leq 50$ samples. The results of $p$-value $(0.032) \&(0.000)<\propto 0.05$ then the data distribution is not normal. The test was continued with a cross tabulation test to see the percentage and distribution of frequency distribution of the relationship between exposure time and blood lead levels of adulterated paint workers, then continued with the correlation test with the Spearman correlation test, it can be seen in table 4 and table 5.

Table 4. Cross Tabulation Test Results of Exposure Time with Blood Lead Levels

\begin{tabular}{lccccccc}
\hline \multirow{2}{*}{$\begin{array}{c}\text { Exposure Time } \\
\text { (hours/week) }\end{array}$} & \multicolumn{3}{c}{ Blood Lead Levels } & \multicolumn{2}{c}{ Total } \\
\cline { 2 - 6 } & \multicolumn{2}{c}{$\leq 0,40 \mathrm{mg} / \mathrm{L}$} & \multicolumn{2}{c}{$>0,40 \mathrm{mg} / \mathrm{L}$} & \multicolumn{2}{c}{$\%$} \\
\cline { 2 - 7 }$\leq 40$ hours/week & $\mathrm{N}$ & $\%$ & $\mathrm{~N}$ & $\%$ & $\mathrm{~N}$ & $\%$ \\
\hline$>40$ hours/week & 9 & $100 \%$ & 0 & $0 \%$ & 9 & $100 \%$ \\
\hline Total & 25 & $80,6 \%$ & 6 & $19,4 \%$ & 31 & $100 \%$ \\
\hline
\end{tabular}

The results of the cross-tabulation test to see the relationship between exposure time and blood lead levels on 40 paint workers was not found by respondents who had lead levels exceeding the reference value limit $(>0.40 \mathrm{mg} / \mathrm{L}) \mathrm{with}$ exposure time $\leq 40$ hours/week. Workers with exposure times $>40$ hours/week found with lead levels exceeding the reference value of $19.4 \%$.

Relationship test with the Spearman correlation test to see the relationship between exposure time and blood lead levels of adulterated paint workers can be seen in the following table:

Table 5. Correlation of Exposure Time and Blood Lead Levels on Adulterated Paint Workers

\begin{tabular}{cccc}
\hline Variable & $\begin{array}{c}\text { Frequency } \\
(\mathbf{n})\end{array}$ & $\boldsymbol{p}$-value & r \\
\cline { 1 - 2 } Exposure Time & 40 & 0.029 & 0.346
\end{tabular}

In table 5, the Spearman correlation test results show that a p-value of 0.029 is obtained with a confidence level of $95 \%$. $\mathrm{p}$-value $\leq \alpha 0.05 \mathrm{r}$-value of 0.346 indicates that there is a significant relationship between exposure time with blood lead levels and the closeness of the moderate relationship between the length of exposure with blood levels of adulterated paint workers.

\section{DISCUSSION}

The results in table 4 are the maximum blood lead levels based on the Reference Guidelines for Heavy Metal Content in the Human Specimens of the Directorate of BPPM, Director General of Medical Services, Ministry of Health of Republic of Indonesia in 2008, in $\mathrm{mg} / \mathrm{L}$ units, which is $\leq 0.40 \mathrm{mg} / 1$ in the reference limit and $>0.40 \mathrm{mg} / \mathrm{L}$ above the reference limit. From the results of the study note the average blood lead level in 40 respondents adulterated paint workers by $0.15 \mathrm{mg} / \mathrm{L}$, with the lowest level of $0.02 \mathrm{mg} / \mathrm{L}$ and the highest of $0.45 \mathrm{mg} / \mathrm{L}$. Based on the results of blood lead levels, 6 out of $40(15 \%)$ respondents had lead levels exceeding the reference value limit> $0.40 \mathrm{mg} / \mathrm{L}$, respondents who had blood lead levels exceeded the reference value limit were lower than the results of previous studies conducted ( Suci Setyoningsih et al., 2016) in car body painting industry workers, as many as 28 of 32 respondents had blood lead levels 
exceeding the recommended toxic threshold value of $10 \mu \mathrm{g} / \mathrm{dL}$ or $0.1 \mathrm{mg} / \mathrm{L}$ with the lowest lead value of 5.1 According to Ardillah (2017) large doses (concentrations) and prolonged exposure can have severe effects and can be dangerous and can affect $\mathrm{Pb}$ exposure in the blood. In addition, based on surveys and interviews with respondents, many workers already have a level of awareness to conduct good PHBS behavior, one of them doing the habit of washing hands before and after work, of 40 respondents only 1 respondent who did not practice hand washing both before and after work.

Modification of the length of service in this study will affect the duration of lead exposure and is associated with blood lead levels. From the results of the study, respondents who had just worked for 3 years had higher lead levels above the reference value $(0.44 \mathrm{mg} / \mathrm{L})$ and were higher compared to respondents who had worked for 60 years $(0.42 \mathrm{mg} / \mathrm{L})$. This study is in line with research (Pusparini, Setiani and D, 2016) that the working period of car painting workers who are $\leq 5$ years and who are $>5$ years have the same risk of an increase in blood lead levels so that it is concluded there is no relationship between blood lead levels with the respondent's tenure. The results of this study are also in line with research by Sari et al (2016) and Hasan, W. (2013) that there is no relationship between tenure and blood lead levels. In theory, blood lead levels are also influenced by internal factors such as endurance, nutritional status and healthy lifestyle such as smoking. $8 \mu \mathrm{g} / \mathrm{dL}$ or $0.0518 \mathrm{mg} / \mathrm{L}$, the highest is $68.43 \mu \mathrm{g} / \mathrm{dL}$ or $0.6843 \mathrm{mg} / \mathrm{L}$ and an average of $35.00 \mu \mathrm{g} / \mathrm{dL}$ or 0.35 $\mathrm{mg} / \mathrm{L}$. The results of this study are not much different from the results of the study of Muliyadi et al. (2015) the average blood lead level in car painting workers was $0.11 \mathrm{mg} / \mathrm{L}$. This happens because of other exposure modifying factors that cause blood lead levels in each worker to be different.

Unlike the case with research conducted (Ayu, Afridah and Nourma, 2016) which states that there is a significant relationship between years of service and an increase in blood lead levels. Factors that can cause this research contradict with previous studies due to the frequency of mixing and the amount of volume in one mix of oil that is not the same for each respondent, and the possibility of exposure outside the work environment such as exposure to lead pollutants in the air when driving, consuming food and drinks lead contaminated. Table 5 analysis results show that there is a significant relationship between exposure time and blood lead levels in mixed paint workers with moderate and positive relationship. This study is in line with research conducted (Tasya, 2018) which states that there is a significant relationship between lead exposure and the length of a person's working hours. Likewise with the theory conveyed by (Adiwijayanti, 2015) the longer the person works, the more the amount of lead exposure is received.

According to Girsang (2008) in his theory states that for 8 hours, a worker can absorb up to $400 \mu \mathrm{g}$, and add 20 $30 \mu \mathrm{g}$ / day from food, drinks, and air. However (Pusparini, Setiani and D hanani, 2016) in their research stated the opposite that there was no significant relationship between the duration of exposure with lead levels in the blood of respondents in car painting workers. This can be caused by internal and external factors that can affect blood lead levels such as clean and healthy living behavior, and immune factors.

Based on the results of the examination of blood lead levels of mixed paint workers, the average level of $0.15 \mathrm{mg}$ / $\mathrm{L}$ was obtained. This result is not much different from the average blood lead level in car painting workers at $0.11 \mathrm{mg} /$ L in a study by Muliyadi et al. (2015). But it is lower than the study (Setyoningsih et al., 2016) in the car body painting industry worker $0.35 \mathrm{mg} / \mathrm{L}$. This can occur because of the amount of exposure to each different worker, as well as the possibility of being exposed outside the work environment such as lead exposure in the air when driving.

The results of lead levels in this study did not show alarming levels, but exposure to low concentrations in a long time can cause damage to organs. If lead exposure continues, then the body cannot absorb lead in the blood so blood lead will accumulate and become toxic. Prevention of further lead accumulation of workers needs to be done by using PPE such as masks and gloves when working.

\section{CONCLUSION}

There is a significant relationship between the duration of exposure with blood lead levels with a p-value of 0.029 and $r$ value of 0.346 which indicates the closeness of the moderate relationship with the direction of a positive relationship, which means the longer a person is exposed to lead, the higher the lead level in his blood .

\section{ACKNOWLEDGEMENT}

The author would like to thank the Poltekkes Kemenkes Jakarta III and BBLK Jakarta and all individuals involved for their contribution and assistance in the data collection process. 


\section{REFERENCES}

[1] Adiwijayanti, B. R. 2015. Hubungan Karakteristik Individu terhadap Kadar Timbal dalam Darah dan Dampaknya pada Kadar Hemoglobin Pekerja

[2] Percetakan di Kawasan Megamall Ciputat Tahun 2015. Skripsi. Program Studi Kesehatan Masyarakat Fakultas Kedokteran dan Ilmu Kesehatan Universitas Islam Negeri Syarif Hidayatullah. Jakarta.

[3] Agency for Toxic Substance and Disease Registry (ATSDR). 2007. Toxicological Profile for Lead. United State. Department of Health and Human Service. Hal: 7

[4] Annashir, N. N. 2015. Hubungan Kadar Timbal dalam Darah dengan Kadar Hemoglobin (Hb) dan Eritrosit Berbintik Basofilik pada Siswa Sekolah Dasar (SD) di Desa Cinangka Kecamatan Ciampea Kabupaten Bogor Tahun 2014. Tesis. Program Pascasarjana Ilmu Kesehatan Masyarakat Fakultas Kesehatan Masyarakat Universitas Indonesia. Depok.

[5] Ardillah, Y. 2016. Faktor Risiko Kandungan Timbal di dalam Darah. Jurnal Ilmu Kesehatan Masyarakat. Edisi November 2016. Vol. 7, No. 3:150-155.

[6] Bohnert,J. 2010. https://jbohnert.wordpress.com/2010/04/02/venipuncture/. Diakses tanggal 27 Desember 2018

[7] Cahaya, C. 2017. Penentuan Kandungan Logam Timbal (Pb) pada Padi dengan Metode Inductively Coupled Plasma (ICP) di Daerah Perbaungan Kabupaten Serdang Bedagai. Skripsi. Departemen Kimia Fakultas Matematika dan Ilmu Pengetahuan Alam Universitas Sumatera Utara.

[8] Eka, H., dan Mokono, J. 2017. Hubungan Kadar Timbal dalam Darah dengan Hipertensi Pekerja Pengecatan Mobil di Surabaya. Jurnal Kesehatan Lingkungan. Edisi Januari 2017. Vol. 9, No. 1: 65-74.

[9] Endrinaldi. 2010. Logam-logam Berat Pencemar Lingkungan dan Efek Terhadap Manusia. Jurnal Kesehatan Masyarakat. Edisi September 2009_Maret 2010. Vol. 4, No. 1: 42-46.

[10] Gusnita, D. 2012. Pencemaran Logam Berat Timbal (Pb) di Udara dan Upaya Penghapusan Bensin Bertimbal. Berita Dirgantara. Edisi September 2012. Vol. 13, No. 3: 95-101.

[11] Handayanto, E., Nuraini, Y., Muddarisna, N., Syam, N., dan Fiqri, A. 2017. Fitoremediasi dan Phytomining Logam Berat Pencemar Tanah. Malang. UB Press. Hal: 3.

[12] Hasan, Wirsal. 2012. Pencegahan Keracunan Timbal Kronis pada Pekerja Dewasa dengan Suplemen Kalsium. Makara, Kesehatan. Edisi Juni 2012. Vol. 16, No. 1: 1-8.

[13] Hasanah, U. 2011. Kajian Model Pemajanan Asap Rokok terhadap Kadar Logam Berat Produk Pangan Gorengan Berlapis Tepung. Skripsi. Fakultas Teknologi Pertanian Institut Pertanian Bogor. Bogor.

[14] Hidayati, E. N. 2013. Perbandingan Metode Destruksi pada Analisi Pb dalam Rambut dengan AAS. Skripsi. Jurusan Kimia Fakultas Matematika dan Ilmu Pengetahuan Alam Universitas Negeri Semarang. Semarang.

[15] Humairo, M.V., dan Keman, S. 2017. Kadar Timbal Darah dan Keluhan Sistem Syaraf Pusat pada Pekerja Percetakan Unipress Surabaya. Jurnal Kesehatan Lingkungan. Edisi Januari 2017. Vol. 9, No.1: 48-56.

[16] Ismawati, Y., Primanti, A., Brosché, S., Clark, S., Weinberg, J., dan Denney, V. 2013. Laporan Nasional Timbal dalam Cat Enamel Rumah Tangga di Indonesia. Balifokus:Bali.

[17] Lubis, B., Rosdiana, N., Nafianti, S., Rasyianti, O., dan Panjaitan, F. M. 2013. Hubungan Keracunan Timbal dengan Anemia Defisiensi Besi pada Anak. CDK-200. Vol. 40, No.1: 17-21.

[18] Lubis, B., Rosdiana, N., Nafianti, S., Rasyianti, O., dan Panjaitan, F. M. 2013. Hubungan Keracunan Timbal dengan Anemia Defisiensi Besi pada Anak. $C D K-200$. Vol. 40, No.1: 17-21.

[19] Lutfi, I., Yustina., dan Ahmad, D. 2017. Analisis Kadar Timbal (Pb) dan Hemoglobin (Hb) pada Petugas Pengecatan Mobil di Bengkel Auto Blitz Kota Pekanbaru dan Potensinya Sebagai Rancangan Lembar Kerja Siswa Biologi di SMA. Jurnal Online Mahasiswa. Vol 4, No. 1: 1-13.

[20] Moelyaningrum, A. D. 2016. Timah Hitam (Pb) dan Karies Gigi. Stomatognatic (J.K.G Unej). Vol. 13, No. 12016 : $28-31$.

[21] Mulfiyanti, D. 2017. Bahaya Timbal (Pb) di Industri Pengecatan. Universitas Muliyadi, Mukono, H.J., dan Notopuro, H. 2015. Paparan Timbal Udara Terhadap Timbal Darah, Hemoglobin, Cystatin C Serum Pekerja Pengecatan Mobil. Jurnal Kesehatan Masyarakat. Edisi November 2015. Vol. 11, No. 1 (ISSN 1858-1196): 87-95.

[22] N, Rizkiani. Arrum. 2004. Studi Pajanan Timbal (Pb) pada Pekerja Pengecatan Mobil. Laporan Tugas Akhir. Fakultas Teknik Sipil dan Perencanaan Institut Teknologi Bandung. Bandung

[23] Palar, H. 2004. Pencemaran dan Toksikologi Logam Berat. Jakarta. PT RINEKA CIPTA.

[24] Pusparini, D. A., Setiani, Onny, Yusniar, H. D. 2016. Hubungan Masa Kerja dan Lama Kerja dengan Kadar Timbal (Pb) dalam Darah pada Bagian Pengecatan, Industri Karoseri Semarang. Jurnal Kesehatan Masyarakat. Edisi Juli 2016. Vol. 4, No.3 (ISSN: 2356-3346) : 758-766. 
[25] Raharjo, P., Raharjo, M., dan Setiani, O. 2018. Analisis Risiko Kesehatan dan Kadar Timbal dalam Darah: (Studi pada Masyarakat yang Mengkonsumsi Tiram Bakau (Crassostrea gigas) di Sungai Tapak Kecamatan Tugu Kota Semarang). Jurnal Kesehatan Lingkungan Indonesia. Vol. 7, No.1: 9-15.

[26] Rahayu, M., dan Solihat, M. F. 2018. Toksikologi Klinik. Kementerian Kesehatan Republik Indonesia. Hal: 284. [27] Sari, M.P., Setiani. Onny., dan Joko. Tri. 2016. Hubungan Karateristik Individu dan Pemakaian Alat Pelindung Diri (APD) dengan Kadar Timbal (Pb) dalam Darah pada Pekerja Pengecatan di Industri Karoseri. Jurnal Kesehatan Masyarakat. Edisi Juli 2016. Vol 4, No. 3 (ISSN: 2356-3346) : 817-824

. [28] Selviastuti, R., Hanani D, Y., dan Setiani, O. 2016. Analisis Risiko Kesehatan Pajanan Timbal (Pb) pada Pekerja Karoseri Bus 'X' di Kota Semarang. Jurnal Kesehatan Masyarakat. Edisi Juli 2016. Vol. 4, No. 3 (ISSN: 2356-3346): $871-878$.

[29] Sembel, D. T. 2015. Toksikologi Lingkungan. Edisi 1. Penerbit CV. Andi Offset. Yogyakarta. Hal: $105-111$.

[30] Simeonov, L. I., Kochubovski, M. V., Simeonova, B. G. 2011. Environmental Heavy Metal Pollution and Effects on Child Mental Development. Amsterdam. Springer. Hal: 3.

[31] World Health Organization (WHO). 2018. Lead Poisoning and Health. Available From URL:http://www.who.int/news-room/fact-sheets/detail/lead-poisoning-and-health. Di akses pada tanggal 12 Desember 2018.

[32] Yulaipi, S., dan Aunurohim. 2013. Bioakumulasi Logam Berat Timbal (Pb) dan Hubungannya dengan Laju Pertumbuhan Ikan Mujair (Oreochromis mossambicus). Jurnal Sains dan Seni Pomits. Vol. 2, No. 2, (2013) 2337-3520 hal: $1-6$. 